\title{
DISKURSUS PENGELOLAAN SUMBER DAYA AIR DI INDONESIA (STUDI KASUS TAHUN 2002-2015)
}

\author{
Water Resource Management Discourse in Indonesia \\ (Case Studi 2002-2015)
}

\author{
Dwi Agus Susilo*), Sarwititi Sarwoprasodjo, Musa Hubeis, dan Basita Ginting \\ Departemen Sains Komunikasi dan Pengembangan Masyarakat, Fakultas Ekologi Manusia, Institut Pertanian Bogor \\ ${ }^{*}$ E-mail: dwiaguss11p@app.ipb.ac.id
}

\begin{abstract}
The discourse of water resources management that occurred in Indonesia for more than a decade involving governments and civil society be interesting to watch. The purpose of this study is to interpret and analyze the discourse and argumentation conflicting parties in the public sphere in water resource management in Indonesia in 2002-2015. Benefits of theoretical research is to increase the variety of discourse analysis method. This critical research paradigm using the theory of Communicative Action Habermas who developed the concept of discourse. Using the method of DHA Wodak as a method of discourse rooted in the critical theory of Habermas researchers managed to see the interests behind the making of Law No. 7 of 2004 on Water Resources and arguments used to use legal rationality and everyday language. Water Resources Law 2004 born of global importance that took the interests of katas ha of water and water privatization. Through discourse with distortion-free communication, guarantees the rationality, where the best reliable arguments to challenge oppressive power and hegemonic ideology.
\end{abstract}

Keywords: argumentation, critique, discourse, privatization, public sphere, water right

\section{ABSTRAK}

Diskursus pengelolaan sumber daya air yang terjadi di Indonesia lebih dari satu dekade yang melibatkan pemerintah dan masyarakat sipil menarik untuk diamati. Tujuan penelitian ini adalah menafsirkan dan menganalisis diskursus dan argumentasi pihak-pihak yang berkonflik di ruang publik dalam pengelolaan sumber daya air di Indonesia tahun 2002-2015. Manfaat penelitian secara teoretis adalah untuk menambah variasi metode analisis diskursus. Penelitian berparadigma kritis ini menggunakan teori Tindakan Komunkatif Habermas yang mengembangkan konsep diskursus. Menggunakan metode DHA Wodak sebagai metode diskursus yang berakar pada teori kritis Habermas peneliti berhasil melihat kepentingan di balik pembuatan UU Nomor 7 Tahun 2004 tentang Sumber Daya Air dan argumentasi yang digunakan menggunakan rasionalitas hukum dan bahasa sehari-hari. UU SDA lahir dari kepentingan global yang membawa kepentingan hak atas air dan privatisasi air. Melalui diskursus dengan komunikasi bebas distorsi menjamin lahirnya rasionalitas, dimana argumentasi terbaik dapat diandalkan untuk menantang kekuasaan yang menindas dan ideologi yang hegemonik.

Kata kunci: argumentasi, kritik, diskursus, privatisasi, ruang publik, hak atas air

\section{PENDAHULUAN}

Munculnya Undang-Undang Nomor 7 Tahun 2004 tentang Sumber Daya Air (UU SDA) menggantikan UU Nomor 11 Tahun 1974 tentang Pengairan menimbulkan perdebatan di masyarakat (Ardhianie 2003; Irianto 2005). Pengelolaan SDA di tanah air yang semula sentralistis berubah menjadi liberal memberikan kesempatan kepada swasta (Wignyosukarto 2005; Nasution 2009) akibat tekanan asing (Hadad 2003; Arianti 2004; Zen 2008).

Prinsip Dublin yang menyatakan air sebagai barang ekonomi telah mendorong upaya-upaya perubahan terhadap pengelolaan sumberdaya air di dunia. Kelangkaan air (water scarcity) dijadikan alasan utama terhadap perubahan cara pandang terhadap air. Pandangan tradisional yang melihat air sebagai barang publik (public goods) milik bersama ( global commons atau sebagai common resources) diganti dengan paradigma pengelolaan air modern yang mendasarkan pada nilai ekonomi intrinsik (intrinsic value) air (Sanim 2011). Hak kepemilikan atas air pun diperebutkan mulai dari kepemilikan oleh negara, komunitas, dan individu. Perdebatan kedua paradigma di atas tidak lepas dari rejim hak (regimes of property rights) terhadap sumberdaya alam, di mana dikenal tiga hak, yaitu state property, community property, dan private property (Fauzi 2004).

Kepentingan swasta berhadapan dengan hak masyarakat untuk melestarikan dan melindungi ekologi, sosial dan budaya mereka melalui air sebagai sumber daya bersama (FAO 2012; Mcclinton 2012). Akibat pengelolaan sumber daya air oleh perusahaan air minum yang melebihi kapasitas telah mengakibatkan warga mengalami kesulitan air dan kekeringan lahan pertanian di banyak daerah. Menurut Wadi (2014) privatisasi dan kooptasi air dari sumber kehidupan kolektif menjadi komersialistik tidak koheren dengan elemen konstitutif yang mengatur tentang "keberlanjutan hidup kolektif" dan "sebesar-besar kemakmuran rakyat".

Perdebatan antara masyarakat sipil dan pemerintah serta swasta terhadap UU SDA tidak lepas dari perspektif di atas, hingga akhirnya lewat Putusan Mahkamah Konstitusi (MK) dinyatakan UU SDA bertentangan dengan UUD 1945 dan tidak memiliki kekuatan hukum mengikat. Dinamika diskursus berupa kontestasi argumen di dalam opini ruang publik terlihat dalam proses pembahasan RUU SDA dan penolakan 
terhadap implementasi UU SDA. Pinter (2004) menyebutkan bentuk ruang publik dapat berwujud pembicaraan di berbagai tempat. Cox (2009) memaknai ruang publik dapat muncul dalam berbagai bentuk tidak hanya kata-kata: gambar dan aksi simbolik nonverbal, seperti aksi duduk-duduk, spanduk, fotografi, film, dan ajuga diskusi, debat yang memberikan pengaruh pada masyarakat luas.

Berakar pada teori tindakan komunikatif, diskursus Habermas adalah bentuk komunikasi di mana para peserta komunikasi tidak lagi dapat memakai begitu saja pernyataan-pernyataan yang sudah diterima bersama, karena komunikasi telah menjadi reflektif dan menuntut alasan-alasan rasional. Rasional di sini berarti diperlukannya klaim-klaim kesahihan (validitas claim) yang didukung oleh penjelasan (Erklärung) dan pemberian alasan (Begründung) (Hardiman 2008; Hardiman 2009) dengan tujuan menghasilkan konsensus di antara para peserta diskursus (Vass 1998 dalam Titscher et al. 2009).

Diskursus memerlukan penguasaan kompetensi komunikatif untuk menyampaikan argumentasi dengan benar, tepat, dan jujur untuk mencapai pemahaman bersama tanpa paksaan (Habermas 1979). Untuk itu diperlukan pragmatika universal yaitu kompetensi komunikatif yang mengintegrasikan kompetensi linguistik (kemampuan gramatikal bahasa-langue) dan kompetensi makna pragmatik sebuah tuturan (penggunaan bahasa --parole) dalam sebuah situasi tindaktutur (speech-act situation) (McCharty 2006).

Penelitian kualitatif adalah penelitian untuk mendapatkan pemahaman (verstehen) sehingga tujuan penelitian ini adalah menafsirkan dan menganalisis diskursus dan argumentasi pihak-pihak yang berkonflik di ruang publik dalam pengelolaan sumber daya air di Indonesia tahun 2002-2015. Manfaat penelitian secara teoretis adalah untuk menambah khasanah metode analisis diskursus dan argumentasi dan secara praktis memberikan pemahaman atas diskursus pengelolaan sumber daya air (SDA).

\section{METODE PENELITIAN}

Penelitian ini menggunakan paradigma kritis dengan menggunakan teori kritis Jürgen Habermas Mazhab Frankfrut, sebagai ilmu empiris yang bersifat filosofis kritis, historis dan juga bersifat praktis emansipatoris (McCharty 2006; Agger 2003; Hardt 2007).

Penelitian studi kasus ini menghimpun perhatian pada penelaahan di seputar kejadian pengelolaan sumber daya air di Indonesia (Nisbet \& Watt 1994) memperhatikan keterbingkaian (boundedness) dan pola-pola perilaku sistem (Denzin dan Lincoln 2009) selama kurun waktu tahun 2002 hingga 2015 (Stake 1995 dalam Creswell 2010). Lokasi penelitian studi kasus ini dilakukan di Jakarta khususnya mengamati dan menganalisa perdebatan yang terjadi di ruang sidang MK.

Teknik pengumpulan data pada analisis teks dan diskursus dilakukan dengan mengumpulkan korpus teks berupa dokumen, pendapat, opini, percakapan, perdebatan dengan memperhatikan keterkaitan teks (Titscher et al 2009; Wooffitt 2005; Goodman 2010) tentang pengelolaan sumber daya air yang terekam secara langsung atau di dalam berita dan opini di media massa dan opini di ruang publik selama kurun waktu 2002-2015. Korpus dalam penelitian ini sebanyak 160 teks yang dibagi menjadi 3 (tiga) sub korpora yaitu berita sebanyak 79 teks, opini berjumlah 30 teks, dan sidang MK sebanyak 51 teks, mengikuti pembagian Baker (2008). Data dilengkapi dengan dokumen, laporan, keputusan organisasi, hasil pertemuan/konferensi, buku, jurnal, risalah penyusunan RUU SDA, dan peraturan perundang-undangan. Sumber dari internet diutamakan mengingat internet telah memberikan harapan potensi rekonfigurasi debat publik menuju model partisipasi ruang publik (Gerhards \& Scäfer 2009).

Validitas dalam penelitian kualitatif ini dilakukan dengan pendekatan triangulasi pada empat tingkat, yaitu teks, intertekstual dan interdiskursifitas, konteks, dan konteks sosial-politik (Meyer 2001; Reisigl \& Wodak 2009). Konteks dipahami bersifat sejarah.

Analisis mikro dilakukan dengan melakukan analisis linguistik kritis dengan fokus pada intertekstualitas, interdiskursivitas, dan metafora. Analisis tingkat meso dilakukan dengan analisa diskursus kritis dan analisa argumentasi yang terkiat dengan konteks tuturan. Analisis tingkat makro dilakukan dengan analisis diakronis historis dengan metode hermeneutika kritis untuk mengetahui makna dalam pengelolaan SDA. Metode analisis mengikuti metode discourse-historical approachDHA Wodak yang menggunakan Habermas' LanguagePhilosophy dalam penyusunan metode DHA (Wodak \& Meyer 2009; Forchtner \& Tominc 2012). Wodak memandang diskursus (discourse) sebagai bentuk struktur dari pengetahuan dan memori praktik sosial dimana teks merujuk pada ungkapan ucapan langsung atau dokumen tertulis. Konsep critique, power, dan ideology menjadi konsep kunci dalam DHA (Fochtner 2011). DHA menggunakan pendekatan linguistik yang kuat, hermeneutika, semiotika, dan teori argumentasi untuk mengamati apolitik dan membangun kerangka kerja konseptual untuk diskursus politik (Wodak \& Meyer 2009). Untuk membantu analisis diskursus dilengkapi dengan analisis corpus linguistic seperti dilakukan Mautner (2007) dalam penelitiannya menggunakan perangkat lunak yang menghasilkan KWIC (keyword-in-context) konkordan, dan frekuensi kemunculan.

\section{HASIL DAN PEMBAHASAN}

Hasil analisis disajikan dalam bentuk analisis tiga tingkat, meliputi tingkat mikro dari hasil analisis teks, tingkat meso dari analisis konteks, dan tingkat makro dari analisis sosialpolitik. Metode DHA dari Wodak ini memberikan pemahaman yang utuh terhadap pengamatan diskursus karena tidak terjebak pada maka teks semata atau memahami konteks yang parsial tetapi memahami secar keseluruhan teks, konteks, dan sosial-politik secara utuh.

\section{Diskursus Pengelolaan Sumber Daya Air di Indonesia 2002-2015}

Analisis diskursus pengelolaan SDA mengikuti DHA Wodak (2001) Wodak dan Meyer (2009) dilakukan dengan melihat pada berbagai arena tindakan politik (field of action), menyertakan beragam genre (genres) dan beragam topik diskursus (discourse topics), strategi diskursif (discursive strategies), makna bahasa (linguistic means), dan kontek penggunaan bahasa (context-dependent realization).

\section{Topik Diskursus}

Topik diskursus pengelolaan SDA yang diamati dari berbagai arena tindakan politik, menyertakan beragam genre dan beragam topik diskursus dapat dilihat pada Gambar 1. Posisi bentuk elips menunjukkan hubungan interdiskursivitas antar 


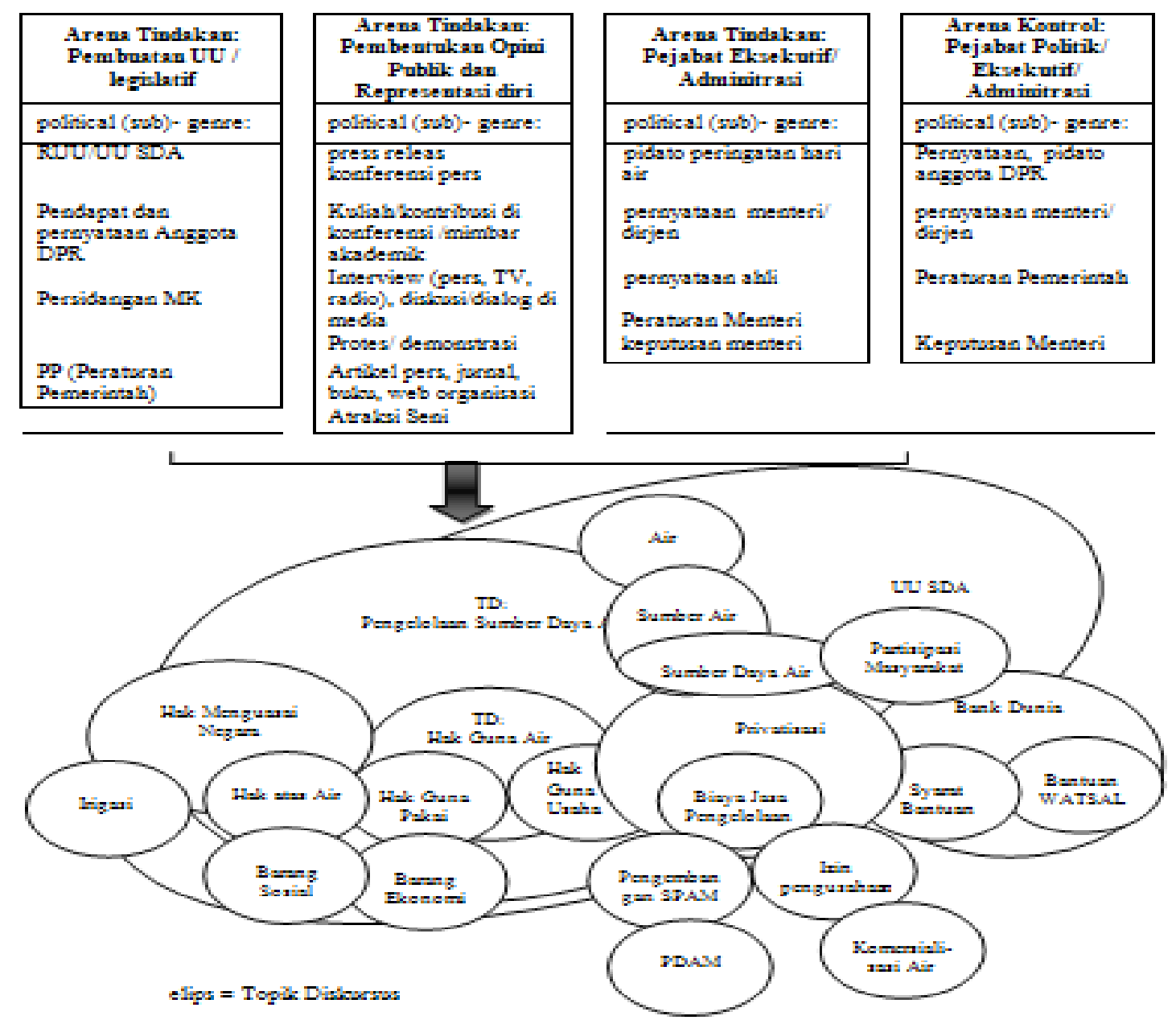

Gambar 1. Arena tindakan, genre, dan topik diskursus terpilih dalam diskursus pengelolaan SDA di Indonesia

topik diskursus. Topik diskursus ini dikonfirmasi dengan software Antconc versi 3.4.4w yang memiliki kemampuan KWIC (keyword-in-context) menunjukkan terma 'privatisasi' memiliki frekuensi kemunculan sebanyak 517, 'hak guna usaha air' sebanyak 304, dan 'izin' sebanyak 525 kali dari total jumlah kata di korpus sebanyak 410.782 kata dengan jenis kata sebanyak 164.96 jenis.

\section{Strategi Diskursus}

Strategi sebagai rencana tindakan yang kurang lebih otomatis menjadi perantara antara tujuan yang ingin dicapai oleh para komunikator dan realisasi dari tujuan-tujuan tersebut (Projektteam dalam Titscher et al. 2009:259). Strategi diskursif membantu dalam melihat identitas para pelaku komunikasi. Identitas menyangkut ideologi, penamaan, dan perilaku dalam tindakan. Strategi diskursif yang dilakukan oleh masingmasing pihak dapat dilihat pada Tabel 1.

Dalam strategi predikasi, penggunaan identitas para aktor memperhatikan pembagian aliran ideologi oleh Dharmawan (2007) dengan sedikit perubahan seperti kapitalisme yang disebut dengan liberalisme atau neo-liberalisme dan ekologisme yang disebut environmentalisme.

\section{Makna Bahasa dalam Konteks UU SDA}

Hasil temuan terkait makna bahasa dalam konteks pengelolaan
SDA di Indonesia dibatasi pada topik diskursus hak guna usaha air. Diskursus hanya bisa dipahami dan diinterpretasikan dalam konteks tertentu yang melingkupinya. Dalam diskursus pengelolaan SDA, hak guna usaha memiliki makna yang berbeda dengan hak guna usaha dalam diskursus agraria. Menurut Al'Afghani (2006) hak guna air mencirikan apa yang secara umum disebut dengan water right (hak air). Maknanya juga berbeda untuk penutur yang berbeda, seperti makna hak guna air yang disampaikan oleh Agoes Widjanarko, Sekjen Kementerian PU: “... maka hak guna usaha air tidak dimaksudkan untuk memberikan hak pengusahaan atas sumber daya air, sungai, danau, atau rawa. Penjelasan umum angka 2 menyatakan bahwa hak guna air bukan merupakan hak pemilikan atas air tetapi hanya terbatas pada hak untuk memperoleh dan memakai atau mengusahakan sejumlah air sesuai dengan alokasi yang ditetapkan oleh pemerintah kepada pengguna air." Adapun Imam Anshori, ahli pemerintah mengatakan, "Sedangkan hak guna usaha air ini adalah hak untuk memperoleh dan mengusahakan air yang terdapat pada suatu sumber air untuk tujuan di luar kebutuhan dasar yang bersifat personal untuk diusahakan, diolah, dikemas lebih lanjut sebagai benda atau jasa, atau sebagai sarana pendukung proses menghasilkan produk dan jasa tertentu yang daripadanya seseorang itu dapat memperoleh pendapatan atau penghasilan".

Wignyosukarto (2005) dalam tulisannya menyebutkan, “... karena akses pemegang Hak Guna Usaha Air atas sumber 


\begin{tabular}{ll}
\hline \multicolumn{1}{c}{ Strategi Diskursif } & \multicolumn{1}{c}{ Kegunaan } \\
\hline Strategi Nominasi & Konstruksi diskursif aktor sosial: \\
& Penyusun RUU SDA : Menteri Kimpraswil, Anggota DPR \\
$\begin{array}{l}\text { (Sebutan terhadap orang, objek, fenomena/ kejadian, } \\
\text { proses, tindakan yang berhubungan dengan }\end{array}$ & Profesional : pembuat kebijakan, konsultan \\
pengelolaan SDA) & Kolektif : masyarakat, generasi mendatang \\
& Ekonomi: PDAM, industri AMDK, industri, pelanggan \\
& Konstruksi diskursif objek/fenomena/kejadian: \\
& Konkret: sumber air, sungai, waduk, danau, sawah, desa, kota \\
& Abstrak: SPAM, hak atas air, hak air, hak menguasai negara, biaya \\
& JPL, barang sosial, barang ekonomi, konservasi, izin pengelolaan \\
& air, prinsip pengelolaan air terpadu
\end{tabular}

Konstruksi diskursif proses dan tindakan:

Material: ketersediaan air, keterbatasan air, kebutuhan air, air minum, air irigasi, air industri, pengelolaan SDA

Mental: penolakan, dukungan

Verbal: pengujian UU SD di MK, dialog di media, pendapat di media/internet

\title{
Strategi Predikasi
}

(Karakteristik, kualitas, dan keistimewaan yang dilekatkan ke aktor sosial, objek, fenomen/ kejadian, dan proses)

\author{
Strategi Perspektivisasi \\ (Perspektif dari ekspresi di nominasi, atribusi, dan \\ argumen)
}

\section{Karakter/Kualifikasi diskursif para aktor:}

Liberal: pendukung pasar bebas privatisasi, peran swasta, pengelolaan SDA terpadu, efisien dan berkeadilan, mengorbankan kepentingan publik (pendukung UUSDA)

Nasionalis: hak menguasai negara, pengelolaan BUMN/BUMD, demokrasi ekonomi, tidak efisien (penolak UU SDA)

Pembela HAM: pemenuhan hak atas air, hak menguasai negara, menolah hak guna usaha air (penolak UU SDA)

Environmentalis: konservasi SDA, generasi mendatang (pendukung dan penolak UU SDA)

Posisi sudut pandang dan ekspresi

Perspektif ideologi: neo-liberal versus nasionalis-pembela HAM

Perspektif kekuasaan: pengura-ngan kekuasaan negara versus peningkatan kekuasaan negara

Sumber: analisis penulis

daya air dalam lokasi tertentu yang diberikan padanya, tidak akan terbuka bagi setiap orang untuk melakukan kontrol yang efektif." Salamudin Daeng, ahli pemohon, dalam sidang MK menandaskan, "Dengan hak guna air, maka swasta mengelola sumber daya air dapat mengelola sumber daya air untuk kepentingan-kepentingan komersial dan mungkin dapat diperjualbelikan pada tingkat harga perekonomian. Dengan demikian, maka negara tidak lagi memiliki tanggung jawab untuk menyediakan air bagi kebutuhan masyarakat secara terjangkau."

Terlihat perbedaan makna dari para pihak terhadap terma yang sama "hak guna usaha air". Pemerintah meyakini hak guna usaha air tidak akan merugikan masyarakat karena tidak ada kepemilikan sumber air dan batasan bagi pengguna lainnya. Kebalikannya, pemohon dari organisasi masyarakat sipil menganggap hak guna usaha air sebagai pembatasan akses bagi pengguna lain dan berpotensi membuat air sebagai komoditas ekonomi yang mahal.

\section{Konteks Sosial Politik Pengelolaan SDA di Indonesia Tahun 2002-2015}

Lahirnya UU SDA tidak terlepas dari agenda global mengenai reformasi tata kelola air. Konferensi Air dan Lingkungan di Dublin tahun 1992 yang menghasilkan Prinsip Dublin dan KTT Bumi 1992 di Rio Jeneiro yang menghasilkan Agenda 21 (Solanes \& Villareal 1999; Kramer \& Wostl 2014) menjadi awal bagi reformasi tata kelola air dunia.
Kesepakatan internasional ini dilanjutkan oleh Global Water Partnership (GWP) dengan menyebutnya menjadi Prinsip Dublin-Rio yang menekankan air sebagai barang ekonomi dan pengelolaan sumber daya air terpadu (IWRM- integrated water resource management) sebagai dasar pengelolaan yang efisien dan adil serta berkelanjutan dalam penggunaan air (Kramer \& Wostl 2014). Istilah IWRM juga digunakan oleh World Water Forum (WWF) (Snellen \& Schrevel 2004), World Water Assesment Programme (WWAP), UNESCO, UN Water, UNEP-DHI Centre of Water and Environent, Stockholm International Water Institute (SIWI), dan International Union for Conservation of Nature (UICN) (Kramer \& Wostl 2014).

Sebagai tindak lanjut kesepakatan internasional tersebut, Bank Dunia mengeluarkan the 1993 World Bank Policy Paper berjudul Improving Water Resources Management dan World Bank Resources Sector Strategy of 2004 untuk memandu praktik dalam penerapan IWRM (Snellen \& Schrevel 2004). Jika selama tiga dekade sebelumnya Bank Dunia memfokuskan investasinya pada infrastruktur sumber daya air, maka sejak 1993 Bank Dunia mengalihkan perhatiannya pada reformasi hukum dan institusional untuk mengefisienkan mekanisme pasar air dunia (WB 1993). Menurut Tsur, pengakuan air sebagai barang ekonomi menjadi ide ekonomi untuk efisiensi alokasi air mendapatkan kepentingannya di dalam kebijakan pemerintah (Boelens \& Vos 2012).

Di Indonesia, Bank Dunia pada 1997 memberikan laporan 


\begin{tabular}{|c|c|c|c|c|}
\hline No & Topik & Pemerintah & Masyarakat & Klaim Kesahihan \\
\hline 1 & Paradigma & $\begin{array}{l}\text { Air sebagai barang sosial, } \\
\text { ekonomi, \& lingkung-an -> water } \\
\text { right (Dublin Principle) }\end{array}$ & $\begin{array}{l}\text { Air sebagai barang sosial (Human } \\
\text { Right Based Approach - HRBA)> } \\
\text { right to water }\end{array}$ & $\begin{array}{l}\text { Klaim ketepatan } \\
\text { (rightness) }\end{array}$ \\
\hline 2 & $\begin{array}{l}\text { Hak Menguasai } \\
\text { Negara (kepemilikan) }\end{array}$ & $\begin{array}{l}\text { Dikuasai negara dengan } \\
\text { pemberian hak guna air }\end{array}$ & $\begin{array}{l}\text { Dikuasai negara tanpa hak guna } \\
\text { air (open access dikelola dengan } \\
\text { Community-based Water Law) }\end{array}$ & $\begin{array}{l}\text { Klaim ketepatan } \\
\text { (rightness) }\end{array}$ \\
\hline 3 & Hak Guna Air & $\begin{array}{l}\text { HGU Air untuk peng-usahaan air } \\
\text { oleh pribadi atau perusahaan }\end{array}$ & $\begin{array}{l}\text { Menolak adanya Hak Guna Usaha } \\
\text { Air yang akan menguasai sumber } \\
\text { air }\end{array}$ & $\begin{array}{l}\text { Klaim ketepatan } \\
\text { (rightness) }\end{array}$ \\
\hline 4 & $\begin{array}{l}\text { Barang ekonomi } \\
\text { (full cost recovery) }\end{array}$ & $\begin{array}{l}\text { menjadikan air bernilai } \\
\text { ekonomis membuat orang harus } \\
\text { berpikir ribuan kali sebelum } \\
\text { menggunakan air dengan sia- } \\
\text { sia. Memenuhi prinsip 4E1C } \\
\text { (Efficiency, Environmen, Equity, } \\
\text { Empowerment and Conflict } \\
\text { reduction) }\end{array}$ & $\begin{array}{l}\text { Ditolak, membuat masyarakat } \\
\text { miskin tidak dapat mengakses air } \\
\text { karena harganya yang semakin } \\
\text { mahal. Hak atas air menjadi tidak } \\
\text { dapat terpenuhi }\end{array}$ & $\begin{array}{l}\text { Klaim ketepatan } \\
\text { (rightness) }\end{array}$ \\
\hline 5 & Pengelolaan SDA & $\begin{array}{l}\text { Integrated Water Resources } \\
\text { Management (IWRM) adanya } \\
\text { public-private partnership, } \\
\text { Private Sector Participation, dan } \\
\text { pelibatan partisipasi warga }\end{array}$ & $\begin{array}{l}\text { Menolak swastanisasi. } \\
\text { Dikelola oleh negara melalui } \\
\text { BUMN atau BUMD }\end{array}$ & $\begin{array}{l}\text { Klaim kebenaran } \\
\text { (truthness) \& } \\
\text { Klaim ketepatan } \\
\text { (rightness) }\end{array}$ \\
\hline
\end{tabular}

Sumber: analisis penulis

perlu segeranya Indonesia mengadakan perubahan dalam pendekatan, cara pandang dan implementasi pengelolaan sumber daya air dari penyediaan air untuk pertanian ke alokasi air yang lebih merata bagi sektor-sektor lain (Kartodiharjo \& Jhamtani 2006).

Krisis moneter 1997 yang melanda Indonesia membuat Bank Dunia menawarkan pinjaman sector and macroeconomic policy reform program dan structural adjustment loan (SECALs and SALs) untuk mengatasi defisit neraca pembayaran dengan syarat dilakukan perubahan struktural (kelembagaan, peraturan dan pengelolaan). Awalnya dengan nama NATSAL (Natural Resources Structural Adjustment Loan) yang mencakup sektor kehutanan, pertanian dan sumberdaya air. Dalam persiapannya NATSAL dipecah menjadi AGSAL dan FORSAL yang didalamnya hanya yang berkaitan dengan sektor pertanian, kehutanan dan sumberdaya air. Kemudian program AGSAL mengerucut lagi menjadi Water Resources Sector Adjusment Loan (WATSAL) yang hanya berkaitan dengan sektor sumber daya air (Chalid 2009; WB 2000). Pemerintah dan Bank Dunia kemudian menyepakati pinjaman WATSAL sebesar US\$ 300 juta dengan jangka waktu pengembalian 15 tahun sebagai bagian integral dari reformasi makro ekonomi dan upaya memperbaiki neraca pembayaran (Kartodiharjo \& Jhamtani (ed.) 2006). Pencairan pinjaman dilakukan dalam tiga tahap, tahap pertama dicairkan pada Mei 1999 sebesar US\$ 50 juta setelah loan agreement ditandatangani. Tahap kedua sebesar US\$ 100 juta, dicairkan pada Desember 2001 setelah disahkannya PP Nomor 77 Tahun 2001 tentang Irigasi. Pencairan tahap ketiga, akan dilakukan jika RUU Sumber Daya Air telah disahkan tetapi batal.

WATSAL sesuai dengan dokumen Operational Policy 4.01 Bank Dunia berisi pengajuan perubahan terhadap 10 (sepuluh) isu kebijakan, antara lain: mengubah seluruh peraturan, kelembagaan dan pengelolaan yang dianggap tidak lagi sesuai; reformasi otoritas sumber daya air wilayah sungai Jatiluhur; memantapkan sistem hak guna air (water use right) untuk alokasi air; dan memantapkan sistem berbasis kebutuhan untuk membiayai pengeluaran untuk pemeliharaan dan rehabilitasi saluran irigasi sekunder yang dikelola petani pemakai air (WB 2004).

Tim kerja pemerintah menyusunan draft RUU SDA sejak 2002 sebagai pengganti UU Nomor 11 Tahun 1974 yang dianggap sudah tidak sesuai lagi. Pengajuan RUU SDA oleh Presiden ke DPR RI dilakukan pada 2002 dan UU SDA disahkan pada tahun 2004 dengan turunan implementasi 7 (tujuh) peraturan pemerintah yang dikeluarkan hingga tahun 2014.

Banyak terma atau frasa yang terdapat di UU SDA mengikuti terma yang digunakan pada dokumen lembaga internasional, seperti Bank Dunia, antara lain: water entitlement/water right/ water used right, water use right, water exploitation right, tradable water rights, full cost recovery, operation and maintenance cost, water allocation efficiency, integrated water resource management (IWRM), public-private partnership $(P P P)$, private sector participation (PSP), national apex body, river basin management agencies, water user association (WUA), dan frasa water pricing policy make equity, eficiency, and sustainability.

Pembahasan RUU SDA memang melibatkan organisasi dan masyarakat sipil, juga perguruan tinggi tetapi pelibatan masih sebatas konsultasi yang tidak memberikan kekuatan untuk mendesakkan norma yang diyakini oleh masyarakat sipil. Kekuatan masyarakat sipil kalah oleh kuasa legislatif dan eksekutif dalam membuat peraturan perundang-undangan. 
Argumentasi Penolakan Privatisasi Pengelolaan Sumber Daya Air

Teori Argumentasi Haberrmas menurut Feteris (2003) melakukan eksplorasi dua sisi relasi antara rasionalitas diskursus hukum dan rasionalitas diskursus sehari-hari. Argumentasi sebagai inti dari perdebatan yang rasional dalam diskursus pengelolaan SDA di Indonesia dapat dilihat pada Tabel 2.

\section{Kritik Atas Pengelolaan Sumber Daya Air di Indonesia}

Kritik peneliti atas pengelolaan SDA dari analisis diskursus yang dilakukan dari tiga sudut pandang, yaitu kritik imanen, kritik diagnostik sosial, dan kritik prognostik. Penggunaan terma atau frasa (langue) harus dipahamai dalam tuturan (parole) sehingga dapat dimaknai menurut penuturnya. Dari analisis dapat dilihat penyusun UU SDA tidak lagi memaknai secara netral terma yang ada tetapi menegaskan keberpihakannya pada kepentingan swasta.

Pengajuan RUU SDA sebagai pengganti UU Pengairan terkait dengan perubahan kepentingan global. UU Pengairan yang disahkan pada tahun 1974 mencerminkan kepentingan revolusi hijau yang membutuhkan irigasi untuk pengairan lahan pertanian untuk mendukung kemunculan varietas padi unggul yang responsif terhadap pupuk dan air. Kepentingan tersebut cocok dengan kepentingan pemerintah saat itu yang bertekad mencapai swasembada beras. Sedangkan lahirnya UU SDA memiliki keterkaitan sejarah dengan perubahan paradigma air global, air menjadi barang ekonomi yang dapat dimiliki oleh pribadi/privat. Konsep kepemilikan air dengan hak guna air (water right) menjadi instrumen bagi komodifikasi air. Perorangan/swasta dapat memiliki hak guna usaha terhadap sumber air tertentu dengan jaminan hak dan bukan lagi sekedar ijin pemanfaatan.

Kepentingan liberal kapitalis pasar bebas tercermin dalam kebijakan institusi global mendikte perubahan-perubahan di pengelolaan SDA di banyak negara (Koppen et al. 2007). Terma atau frasa yang digunakan sepertinya netral dan memberikan rasa keadilan bagi semua. Bagi mereka yang tidak memahami ideologi tersebut akan mudah untuk menyetujui dan mendukungnya.

Penelitian berparadigma kritis ini mampu menyingkap ideologi yang digunakan oleh Bank Dunia, lembaga internasional, pembuat UU yang mendukung hak atas air dan mendorong privatisasi dan pemakaian istilah-istilah teknis dan akademis yang sulit dipahami orang awam. Kekuasaan (power) dimainkan dengan penguasaan dan penggunaan terma-terma baru. Melalui kekuasaan untuk menyusun dan menetapkan peraturan perundang-undangan pemerintah dapat menghegemoni rakyat untuk tunduk patuh, penetapan hak guna usaha air atas sumber air tertentu yang mengahalangi akses warga setempat terhadap sumber atau atau seperti kewjiban membayar biaya jasa pengelolaan SDA (full cost recovery) yang memberatkan.

Masyarakat sipil perlu dilibatkan proses penyusunan peraturan perundang-undangan agar mereka dapat mematuhi peraturan yang dibuat oleh wakil mereka. Jika tidak mereka dapat menolak dan membangkang untuk mematuhi peraturan, seperti yang dikemukakan White dan Farr (2012) masyarakat bisa mengatakan tidak dan mengabaikan peraturan. Demokrasi representatif tidak lagi cukup untuk mewadahi kepentingan masyarakat perlu dikembangkan demokrasi deliberatif yang memberikan kekuasaan komunikatif bagi masyarakat sehingga akan dihasilkan peraturan yang dibuat dan dilaksanakan oleh mereka sendiri. Doohm (2010) menyatakan kekuasaan komunikatif tercipta lewat publik yang akan memberikan legitimasi dan jaminan politik yang manjur bagi hak kebebasan dan partisipasi demokrasi.

\section{KESIMPULAN DAN SARAN}

\section{Kesimpulan}

1. Identitas para pendukung UU SDA adalah liberalis sedangkan penolak UU SDA adalah nasionalis-pembela hak asasi manusia. Identitas environmentalis menjadi milik keduanya dengan penggunaan terma konservasi yang saling berbagi.

2. UU SDA lahir dari agenda global reformasi tata kelola air yang masuk ke Indonesia lewat bantuan asing dan mengadopsi terma-terma yang dimiliki oleh jaringan institusi global.

3. Pelibatan masyarakat sipil dalam penyusunan RUU SDA sudah dilakukan tapi masih sebatas konsultatif yang belum mencerminkan demokrasi yang sejati.

4. Komunikasi tanpa distorsi, seperti yang terjadi di persidangan MK, menjamin lahirnya rasionalitas, argumentasi terbaik dapat diandalkan untuk menantang kekuasaan yang menindas dan ideologi yang hegemonik.

\section{Saran}

1. Penggunaan analisis DHA Wodak sebagai alat analisis sosial yang komprehensif dapat digunakan untuk menganalisis pengelolaan sumber daya alam lainnya.

2. Pemerintah, masyarakat, dan swasta harus berupaya melakukan komunikasi dialogis-reflektif sebagai bentuk komunikasi bebas distorsi agar dapat menghasilkan konsensus, khususnya dalam pembuatan peraturan perundang-undangan agar memiliki legitimasi.

3. Jalur hukum dapat menjadi pilihan jika memang diperlukan.

\section{DAFTAR PUSTAKA}

Agger B. 2003. Teori Sosial Kritis: Kritik, Penerapan dan Implikasinya. Kreasi Wacana. Yogyakarta.

Al'Afghani M.M. 2006. Constitutional Court's Review and the Future of Water Law in Indonesia'. Law, Environment and Development Journal. pp.1-18.

Ardhianie N. 2003. Sosialisasi dan Arah Kebijakan RUU Sumber Daya Air. Kompas. 18 Desember 2003.

Arianti V. 2004. Privatisasi di Indonesia: Saran Pelaksanaan dengan Berkaca dari Pengalaman Negara Lain. Global Vol.7 No.1 November 2004. pp. 18-34.

Baker P, C. Gabrielatos, M Khosravnik, M Krzyzanowski, T McEnery, R Wodak. 2008. A useful methodological synergy? Combining critical discourse analysis and corpus linguistic to examine discourses of refugees and asylum seekers in the UK press. Discourse Society. 19; pp. 273.

Boelens R, Vos J. 2012. The danger of naturalizing water policy concept: Water productivity and efficiency discourse from field irrigation to virtual water trade. Agricultural Water Management 108 (2012). Pp. 16-26.

Chalid H. 2009. Hak-Hak Asasi Manusia Atas Air: Studi Tentang Hukum Air di Belanda, India dan Indonesia [Disertasi]. Universitas Indonesia. Depok.

Cox R. 2009. Environtemental Communication And The Public Sphere. 2nd Edition. Sage. Los Angeles. 
Creswell J. 2010. Research Design Pendekatan Kualitatif, Kuantitatif, dan Mixed. Edisi Ketiga. Pustaka Pelajar. Yogyakarta.

Denzin NK, Lincoln YS. 2009. Handbook of Qualitative Research. Pustaka Pelajar. Yogyakarta.

DharmawanA.H. 2007. Dinamika Sosio-Ekologi Pedesaan: Perspektif dan Pertautan Keilmuan Ekologi Manusia, Sosiologi Lingkungan dan Ekologi Politik. Sodality.Vol. 01, No. 01. April 2007. pp. 1-40.

Doohm SM. 2010. Nation state, capitalism, democracy: Philosophical and political motives in the thought of Jürgen Habermas. European Journal of Social Theory 13: pp. 443.

Fauzi A. 2004. Ekonomi Sumber Daya Alam dan Lingkungan: Teori dan Aplikasi. Cet ke-2. Gramedia Pustaka Utama. Jakarta.

[FAO] Food and Agriculture Organization. 2012. Coping With Water Scarcity. An Action Framework for Agricultural and Food Security. FAO UN. Rome.

Feteris ET. 2003. The Rational of Legal Discourse in Habermas's Discourse Theory. Informal Logic. Vol. 23. No. 2: pp. 139-159.

Forchtner B. 2011. Critique, the discourse-historical approach, and the Frankfurt School. Critical Discourse Studies, 8: 1, pp. $1-14$.

Forchtner B., Tominc A. 2012. Critique and Argumentation: on the relation between DHA and pragma-dialectics. Journal Language and Politics 11:1. (2012), pp. 31-50.

Gerhards J, Scäfer MS. 2009. Is the internet a better pubic sphere? Comparing old and new media in the US and Germany. New Media \& Society. XX(X) pp. 1-18.

Goodman S. 2010. "It's Not Racist To Impose Limits On Immigration": Constructing The Boundaries Of Racism In The Asylum and Immigration Debate. Critical Approaches to Discourse Analysis across Disciplines. http://CADAAD. net/ejournal. Vol 4 (1): pp. 1 - 17. ISSN: 1752-3079.

Habermas. 1979. Communication and the Evolution of Society. Beacon. Boston.

Hadad N. 2003. Privatisasi Air Indonesia. INFID Annual 2003. INFID. Jakarta.

Hardiman FB. 2008. Teori Diskursus dan Demokrasi: Peralihan Habermas ke Dalam Filsafat Politik. Diskursus. Vol. 7, No. 1, April 2008: pp. 1-27.

Hardiman FB. 2009. Demokrasi Deliberatif: Menimbang 'Negara Hukum' dan 'Ruang Publik' dalam Teori Diskursus Jurgen Habermas. Kanisius. Yogyakarta.

Hardt H. 2007. Critical Communication Studies: Sebuah Pengantar Komprehensif Sejarah Perjumpaan Tradisi Kritis Eropa dan Tradisi Pragmatik Amerika. Jalasutra. Yogyakarta.

Irianto G. 2005. Nasib Pengelolaan Sumberdaya Air. Kompas. 2 Agustus 2005.

Kartodihardjo H., Jhamtani H. (ed.). 2006. Politik Lingkungan dan Kekuasaan di Indonesia. Equinox Publishing Indonesia. Jakarta.

Koppen Bv, Giardano M, Butterworth J. (eds.). 2007. Communitybased Water Law and Water Resources Management Reform in Developing Countries. CAB International and Biddles Ltd. Oxfordshire.

Kramer A, Pahl-Wostl C.. 2014. The global policy network behind integrated water resources management: is it an effective norm diffusor? Ecology and Society. 19(4): pp. 11.

[MK] Mahkamah Konstitusi. 2014. Risalah Sidang Perkara Nomor 85/PUU-XI/2013 Perihal Pengujian UU Nomor 7 Tahun 2004 Tentang UU SDA tanggal 4 Desember 2013, 29 Januari 2014, dan 12 Februari 2014.

[MK] Mahkamah Konstitusi. 2015. Putusan MK Nomor 085/ PUU-XI/2013. Mahkamah Konstitusi. Jakarta.

Mautner G. 2007. Mining large corpora for social information: The case of elderly. Language in Society 36, pp. 51-72.

McCharty T. 2006. Teori Kritis Jurgen Habermas. Cet ke-4. Nurhadi, penerjemah; Muzir IR, editor. Kreasi Wacana. Yogyakarta.

Mcclinton C. 2012. Politics and Water (Political Issues About Water). University Publ. Delhi.

Meyer M. 2001. 'Between theory, method, and politic:positioning of the approach to CDA' in Wodak R., Meyer M. (ed.). 2001. Methods of Critical Discourse Analysis. Sage Publication Ltd. London.

Nasution I.K. 2009. Bank Dunia \& Politik Privatisasi Air di Indonesia. Jurnal Politeia. Vol. 1. No. 2. Juli 2009. pp. 7688

Pinter A. 2004. Public Sphere and History: Historians' Response to Habermas on the "Worth" of the Past. Journal of Communication Inquiry 28: pp. 217.

Reisigl M, Wodak R. 2009. 'The discourse-historical approach', in Wodak R, Meyer M. (ed.). 2009. Methods of Critical Discourse Analysis. Second Edition. Sage Pubications Ltd. London.

Sanim Bunasor. 2011. Sumberdaya Air dan Kesejahteraan Publik (Suatu Tinjauan Teoritis dan Kajian Praktis). IPB Press. Bogor.

Snellen WB, Schrevel A.. 2004. IWRM: for sustainable use of water 50 years of international experince with the concept of integrated water management. Background document to the FAO/Netherlands Conference on Water for Food and Ecosystems. Ministry of Agriculture, The Netherlands. Waginengan.

Sollanes M, Fernando GV. 1999. The Dublin Principle for Water as Reflected in a Comparative Assesment of Institutional and Legal Arrangement for IWRM. Global Water Partnership. Stockholm.

Titscher S., Wodak R., Meyer M., Vetter E.. 2009. Metode Analisis Teks \& Wacana. Pustaka Pelajar. Yogyakarta.

Wadi H. 2014. Perselisihan Keadilan, Kemanfaaatan, dan Kepastian Hukum dalam Privatisasi Sumber Daya Air. Jurnal IUS. Vol II. Nomor 5 Agustus 2014. pp. 219-239.

White S K., Farr ER. 2012. 'No-Saying” in Habermas. Political Theory. 40: pp. 32.

Wignyosukarto B. 2005 Aroma Privatisasi dalam UU No. 7/2004 tentang Sumberdaya Air. Makalah Seminar Bulanan ke-31 PUSTEP-UGM, Selasa, 2 Agustus 2005.

Wodak R. 2001. 'The discourse-historical approach', in Wodak R, Meyer M. (ed.). 2001. Methods of Critical Discourse Analysis. Sage Pubications Ltd. London.

Wodak R., M. Meyer . 2009. 'Critical discourse analysis: history, agenda, theory and methodology' in Wodak R., Meyer M. (ed.). 2009. Methods of Critical Discourse Analysis. 2nd Edition. Sage Ltd. London.

Wooffitt, R. 2005. Conversation Analysis \& Discourse Analysis: A Comparative and Critical Introduction. Sage Publication. London.

[WB]. World Bank. 1993. Improving Water Resources Management. The World Bank. Washington D.C.

[WB]. World Bank. 2000. Environmental Assessment for Sector Adjustment Loans: The Case of The Indonesia Water Resources Sector Adjustment Loan. East Asia Environment and Social Development Unit. Environmental and Social Safeguard Note. 20932. Number 3. June 2000.

[WB]. World Bank. 2004. Water Resources Strategy: Strategic Directions for World Bank Engagement. The World Bank. Washington DC 20433.

Zen, A.P.M. 2008. Tirani Modal dalam Ketetapan Konstitusional di Indonesia. Paper pada Konferensi Warisan Otoritarian. Jakarta UI, 5 Agustus 2008. 